\title{
The rise of a novel, plankton-based marine ecosystem during the Mesozoic: a bottom-up model to explain new higher-tier invertebrate morphotypes
}

René Hendricus Bartholomeus Fraaije, Barry Wilhelmus Martinus Van Bakel, John Wilhelmus Maria Jagt, Pedro Andrade Viegas

René Hendricus Bartholomeus Fraaije info@oertijdmuseum.nl

Barry Wilhelmus Martinus Van Bakel Pedro Andrade Viegas

Oertijdmuseum, Bosscheweg 80, 5283 WB Boxtel, the Netherlands.

\section{Barry Wilhelmus Martinus Van Bakel}

Naturalis Biodiversity Center, P.O. Box 9517, 2300 RA Leiden, the Netherlands.

\section{John Wilhelmus Maria Jagt}

Natuurhistorisch Museum Maastricht, de Bosquetplein 6-7, $6211 \mathrm{KJ}$ Maastricht, the Netherlands.

BOL. SOC. GEOL. MEX. 2018

VOL. 70 NO. 1

P. $187-200$

http://dx.doi.org/10.18268/BSGM2018v70nla11

\begin{abstract}
Major radiation events amongst a range of phytoplanktonic and zooplanktonic microbiota such as calcareous nannofossils, calpionellids, diatoms, dinoflagellates, planktonic foraminifera and radiolarians are characteristic of the time interval between the Late Jurassic (c. 160 $\mathrm{Ma}$ ) and Late Cretaceous (c. $100-66 \mathrm{Ma}$ ). Both directly and indirectly, these radiations in the marine water column led to a proliferation of various benthic groups such as burying and swimming crabs and irregular echinoids as well as nektonic groups such as ancyloceratine heteromorph ammonites. For each of the invertebrate groups studied we have plotted all available data on their diversity through time. The resultant histograms form the basis of our new model of the 'infill' of Mesozoic ecosystems. The impact on detritus and plankton feeders was direct, from the Late Jurassic onwards, in that an increased supply of planktonic food particles became available. However, the radiation of burying raninoid crabs, which comprised more complex scavengers/detritivores, was intimately linked to the bloom of (part of) their food source (i.e., marine meiofauna). During the Cretaceous Period new innovations and adaptations brought about additional faunal turnovers. For instance, amongst frog crabs (Raninoidia), there was a transition from the palaeocorystid type, via the lyreidid type to the raninid morphology. Similarly, coeval turnovers are documented for irregular echinoids (i.e., from Toxasteridae via Micrasteridae to Schizasteridae) and for heteromorph ammonites: from Ancyloceratoidea via Turrilitoidea to Scaphitoidea. Here we present, for the first time, an elaborated bottom-up model to explain the emergence and dispersion in time of different invertebrate groups at a range of higher-tier trophic levels.
\end{abstract}

Keywords: Mesozoic, marine ecosystem, paleoecology, invertebrate morphotypes.

\section{RESUMEN}

Los mayores eventos de radiación de la microbiota que comprende el fitoplancton y zooplankton, con grupos como nanofósiles calcáreos, calpionélidos diatomeas, dinoflagelados, foraminíferos planctónicos y radiolarios, fueron característicos del intervalo de tiempo comprendido entre el Jurásico Tardío (c. $160 \mathrm{Ma}$ ) y el Cretácico Tardio (c. 100-66 Ma). Tanto de forma directa como indirecta, dichas radiaciones en la columna de agua marina llevaron a la proliferación de varios grupos bentónicos, tales como los cangrejos infaunales y nadadores, equinoideos irregulares, así como grupos nectónicos tales como los ammonites heteromorfos ancilocerátidos. Para cada grupo de invertebrados estudiado, hemos graficado todos los datos disponibles acerca de su diversidad a través del tiempo. Los histogramas resultantes constituyen la base para nuestro nuevo modelo de "relleno" de los ecosistemas del Mesozoico. El impacto sobre los detritófagos y planctotróficos fue directo a partir del Jurásico Tardío, ya que se dió un incremento de partículas nutritivas provenientes del plankton, de tal forma que la radiación de los cangrejos raninoides infaunales (que comprendía los más complejos carroñeros/detritívoros), estuvo intimamente ligada a la explosión de (o parte de) su alimento (i.e., meiofauna marina). Durante el Periodo Cretácico, surgieron innovaciones y adaptaciones en torno a cambios en composición faunística. Por ejemplo, hubo una transición en los cangrejos rana (Raninoidia), entre el tipo palaeocoristido (vía el tipo liréidido), hacia el tipo ranínido. Otros cambios coetáneos se han documentado para equinoideos irregulares (i.e., de Toxasteridae, vía Micrasteridae, a Schizasteridae), y para ammonites heteromorfos, de Ancyloceratoidea, vía Turrilitoidea, a Scaphitoidea. Aquí se presenta, por vez primera, un elaborado modelo a detalle, con el fin de explicar el surgimiento y la dispersión en el tiempo, de diferentes grupos de invertebrados, en el rango de los más altos niveles tróficos.

Palabras clave: Mesozoico, ecosistema marino, paleoecología, morfotipos de invertebrados. 


\section{Introduction}

The notion of a tardy, low-diversity recovery from the Permian-Triassic mass extinction event has to be reconsidered following the paper by Brayard et al. (2017). Outline in that paper was an Early Triassic marine ecosystem with a phylogenetically diverse, functionally complex and trophically multi-level marine ecosystem, from primary producers to top predators and potential scavengers. Thus, ecosystem balance and optimisation were reached not long after the Palaeozoic Era. However, this was merely the first part of the transition from the Palaeozoic to the modern marine evolutionary fauna. A second, essential phase (undeveloped during the Palaeozoic) still had to take place, as demonstrated below. To encompass patterns of widespread evolutionary changes among benthic invertebrates in the marine realm during the Mesozoic (ca. 252 - 66 Ma), Vermeij (1987) coined the term 'the Mesozoic Marine Revolution'. He focused mainly on extinct molluscs and observed a Mesozoic-Cenozoic radiation of durophagous predators. Another, coeval, revolution has been discussed by Knoll and Follows (2016), with reference to marine primary producers, inclusive of radiations of photosynthetic dinoflagellates, coccolithophorids and diatoms.

Mesozoic evolutionary and adaptive radiations in invertebrate groups such as echinoids (e.g., Kier, 1982; Smith, 1984; David et al., 2009; Kroh and Smith, 2010), heteromorph ammonoids (Mikhailova and Baraboshkin, 2009; Lehmann, 2015) and brachyuran decapod crustaceans (e.g., Karasawa et al., 2014; Schweitzer et al., 2016) have also been recorded in considerable detail. However, there was no link or overview in these palaeontological studies between the adaptive radiations observed and a coherent marine food chain revolution that filled an important portion of the modern marine ecosystem. The present paper demonstrates, for the first time, a bottom-up Mesozoic marine revolution model from phytoplankton to diverse nektonic and benthic invertebrate groups (Figure 1).

\subsection{PHYTOPLANKTON}

In order to gauge why several invertebrate groups experienced blooms and proceeded to occupy new ecological niches in Early Cretaceous marine assemblages, the food web at the time needs to be studied from the bottom up. In their bottom-up perspective on ecosystem changes in Mesozoic oceans, Knoll and Follows (2016) provided a mechanism for the observed evolutionary shifts in Mesozoic marine biota on the basis of a phytoplankton radiation and diversification (Figure 2). Stratigraphically and taxonomically, planktonic microfossils provide the most complete record of biodiversity of any group of extinct marine organisms. The phytoplankton record is of particular significance as it tracked global changes in the marine system and, in turn, had an impact on biodiversity and productivity of higher trophic levels of the biosphere. Coccolithophores and other calcareous nannoplankton first appeared in strata of Late Triassic (c. $210 \mathrm{Ma}$ ) age. Rates of speciation at levels significantly above background were confined to the Late Triassic, Early Jurassic and Tithonian-Berriasian intervals (Bown et al., 2004). Another phytoplankton group, the dinoflagellates (single-celled protists at or near the base of the food chain), showed remarkable patterns in species diversity during the Mesozoic. First appearing in the Middle Triassic, they rapidly increased

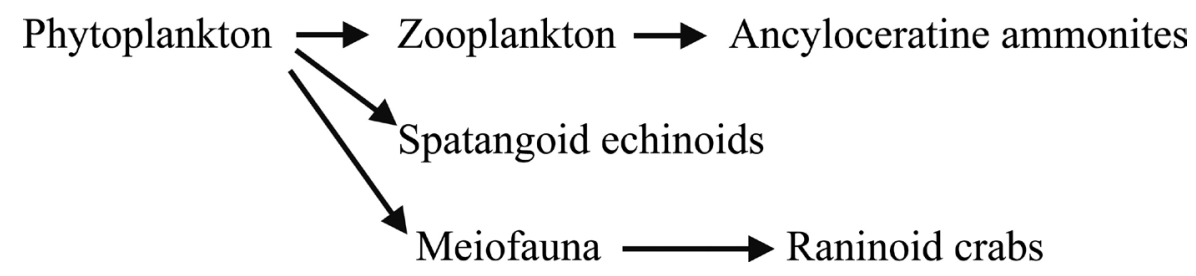




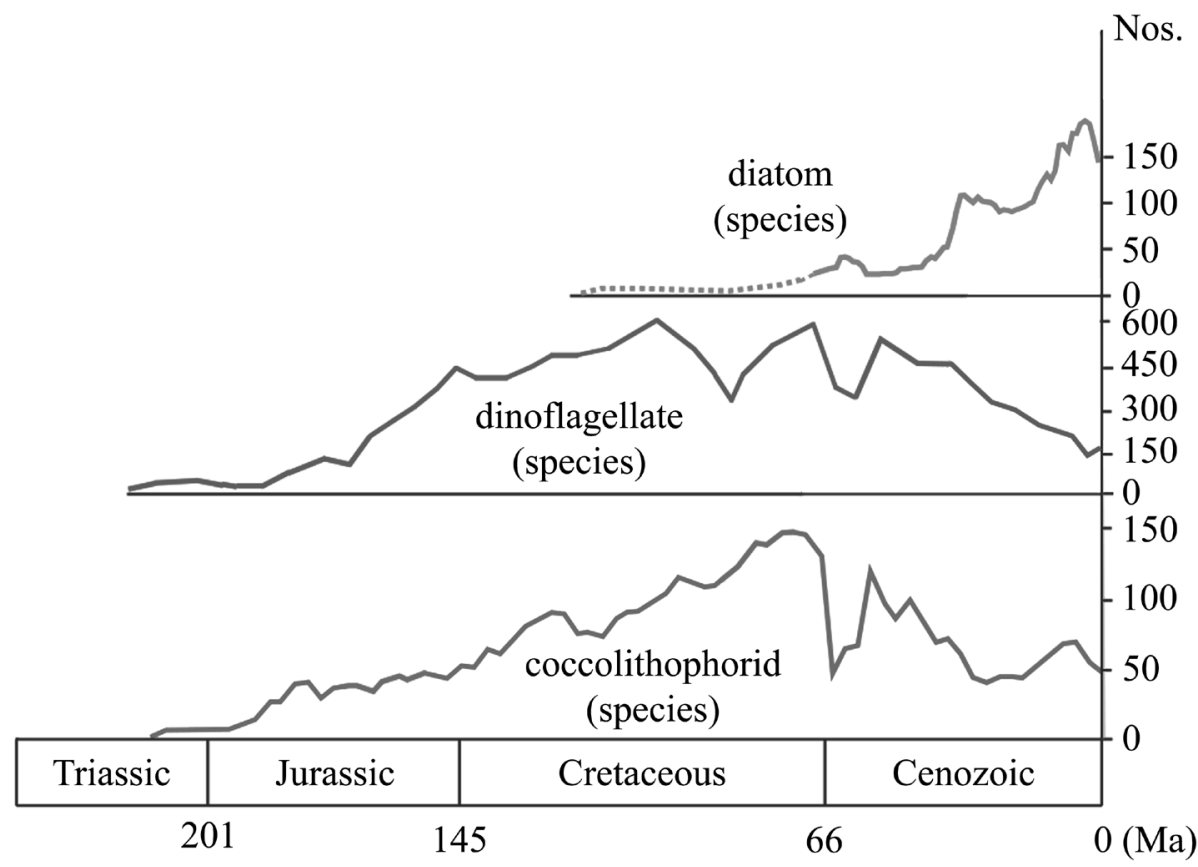

Figure 2 Radiations of species of photosynthetic coccolithophorids, dinoflagellates and diatoms (data from Knoll and Follows, 2016).

to a Late Jurassic maximum of 420 species in the Kimmeridgian (157 - $153 \mathrm{Ma})$. After a minor decline, diversity rose to an all-time peak of 584 taxa during the mid-Cretaceous (Albian; see MacRae et al., 1996). A third group of planktonic forms of importance comprises the enigmatic calpionellids. These marine organisms with calcitic, bellshaped tests ranged, particularly in more basinal environments, from the Tithonian to the Albian (Reháková and Michalík, 1997). Thus, from the Late Jurassic (Tithonian, 152 - $145 \mathrm{Ma}$ ) onwards a marked increase, both in numbers and overall diversity, of phytoplanktonic food items has been documented (Figure 3).

\subsection{ZOOPLANKTON}

In modern seas and oceans distinct zooplankton responses to phytoplankton blooms have been recorded (e.g., Atkinson et al., 1996). In the fossil record there is a striking link between zooplankton (i.e., planktonic foraminifera and radiolarians) abundance and diversity and a phytoplankton increase from the Tithonian to the Late Cretaceous (e.g., Erbacher and Thurow, 1997; Premoli Silva and Sliter, 1999; Bown et al., 2004).

During the Late Palaeozoic and into the Mesozoic, Radiolaria experienced a gradual decline until the end of the Jurassic, at which time there was a rapid diversification. This coincided with a radiation amongst dinoflagellates which may have represented an increased source of food for the Radiolaria (Olney, 2002).

As a result of the increased, continuous 'snowfall' of planktonic remains to the sea floor in offshore settings, from the Tithonian onwards (e.g., Rückheim, 2005), large amounts of food particles were available to allow a radiation of small benthic organisms, collectively known as meiofauna, to take place.

\subsection{HETEROMORPH AMMONITES}

While heteromorph ammonites play almost no role during the earliest Cretaceous, they predominate in numerous faunal assemblages from the early late Hauterivian (c. $130 \mathrm{Ma}$ ) onwards, until the end of the late Maastrichtian $(69-66 \mathrm{Ma})$ or the start of the early Paleocene. Although the link between the proliferation of planktonic groups 
Diversity (number)

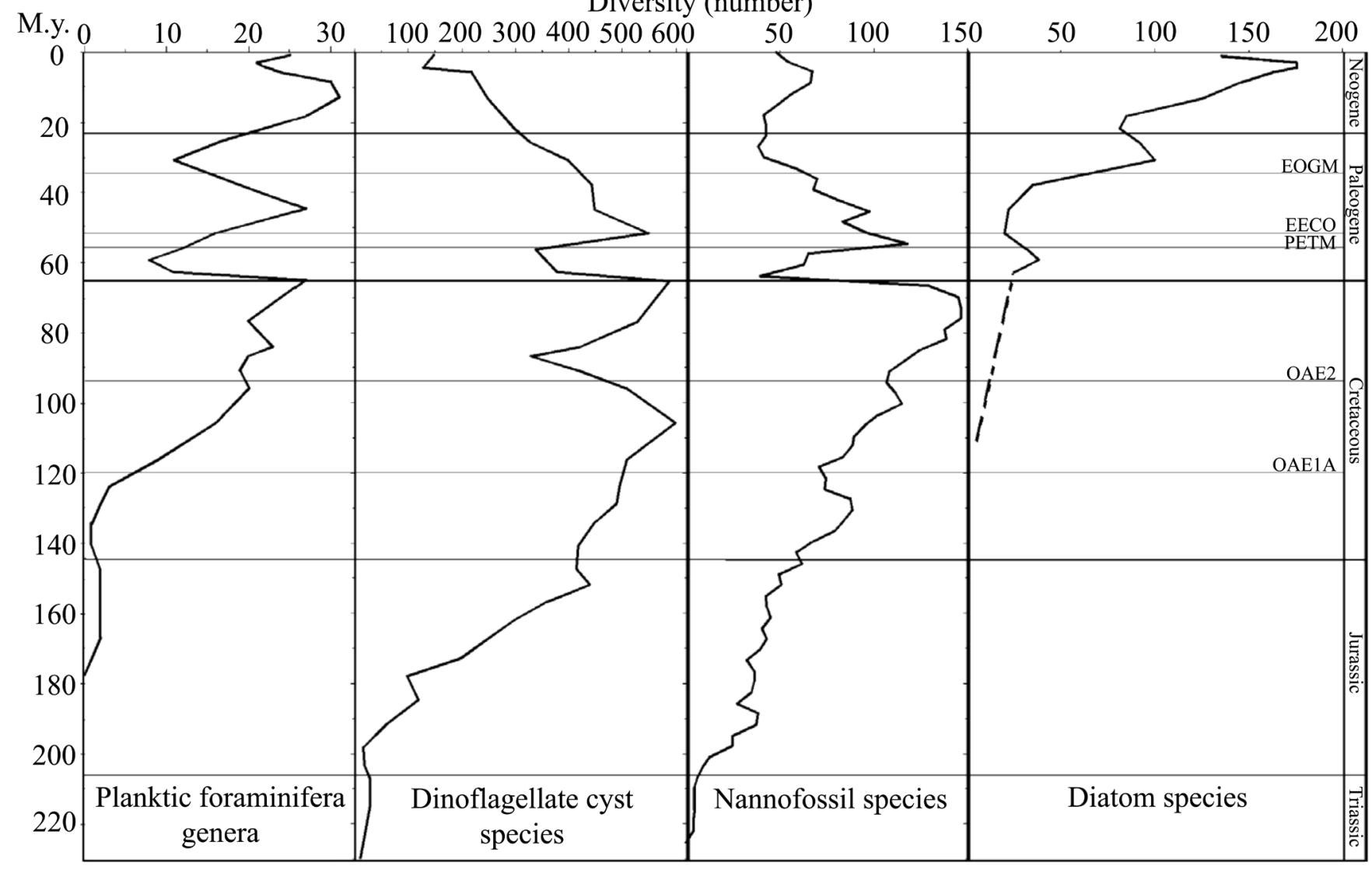

Figure 3 Radiation of zooplankton (planktonic foraminifera) related to the radiation of phytoplankton (modified after Bown et al., 2004 fig. 8).

appears quite obvious, many ammonite workers are still debating the diverse ecological constraints involved (Lehmann et al., 2015). Larger-sized invertebrates that benefited from the total plankton radiation were, first and foremost, nektonic ancyloceratine ammonites that fed directly on and within the planktonic 'clouds' in the water column (e.g., Mikhailova and Baraboshkin, 2009) (Figure $4)$.

During the Albian (mid-Cretaceous, 113 - 100 Ma), a group of ammonites that comprised the superfamilies Scaphitoidea and Turrilitoidea, diversified and replaced the Ancyloceratina which previously had been the predominant heteromorphs (Mikhailova and Baraboshkin, 2009). These two groups remained important elements of Middle and Late Cretaceous ammonite assemblages right up to the latest Maastrichtian and into the earliest Paleocene (Landman et al., 2014,
2015).

In recent years, well-preserved buccal masses of scaphitoid and turrilitoid ammonites have been described in detail (e.g., Kruta et al., 2011, 2013). Three-dimensional reconstructions of the buccal apparatus in these ammonites have revealed a similarity that suggests all of them had adopted similar feeding habits. The morphology of the jaws and radula and the presence of possible prey remains inside the buccal mass makes it likely that these ammonites fed on small organisms in the water column, rather than capturing and eating large prey on the ocean floor, as exemplified by living Nautilus Linnaeus, 1758 (Kruta et al., 2011). The appearance of this plankton-feeding strategy led to the radiation of the so-called aptychophoran ammonites during the Jurassic and Cretaceous, in conjunction with the radiation of new groups of plankton as discussed herein. Understanding the 


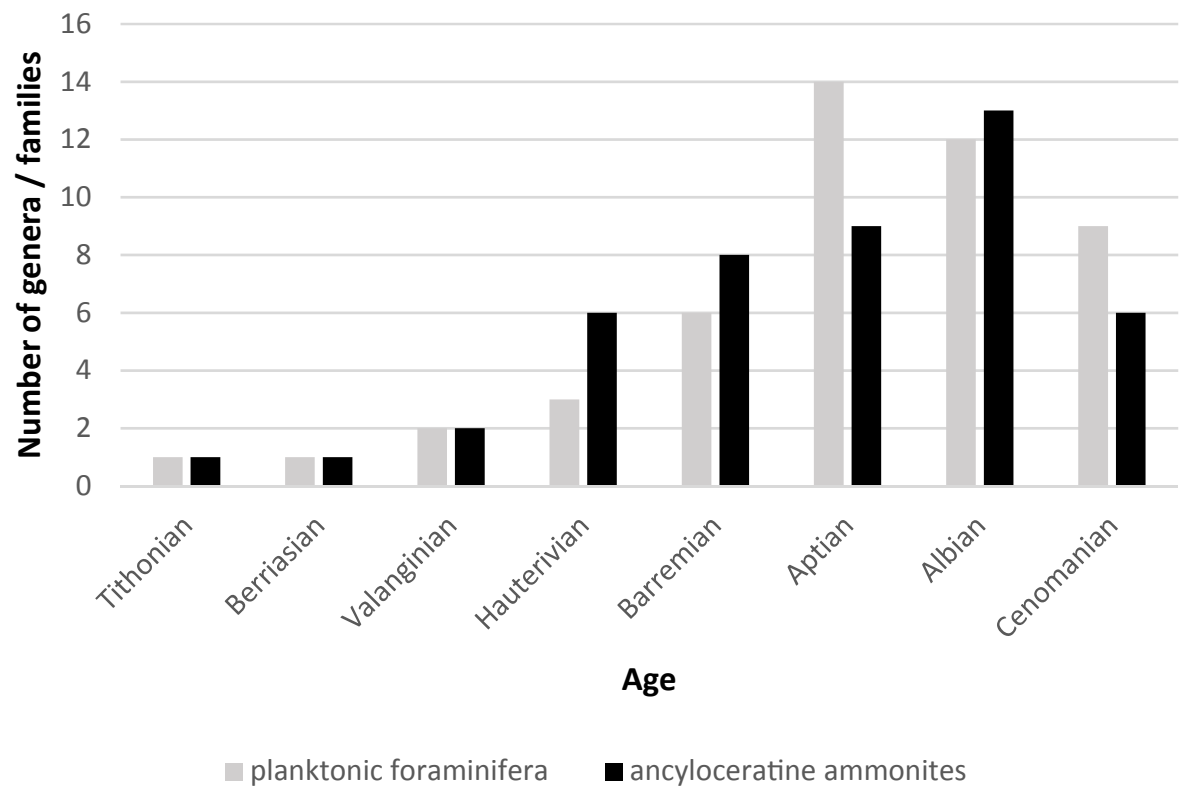

Figure 4 Successive radiation in time of numbers of planktonic foraminiferal genera and of ancyloceratine ammonite families (data from Rückheim, 2005; Mikhailova and Baraboshkin, 2009).

role of these ammonites in the new Mesozoic food web provides insights into their radiation in the Jurassic, as well as their extinction at the end of the Cretaceous or during the earliest Paleogene (Kruta et al., 2011; Landman et al., 2014, 2015). Phylogenetic studies of the ontogeny and sutural morphology have established that Turrilitoidea and Scaphitoidea together comprise a monophyletic group, with the former derived from Ancyloceratoidea and the latter from the Turrilitoidea (Monks, 1999).

\subsection{IRREGULAR EGHINOIDS}

Spatangoids ('heart urchins') originated during the early Berriasian, c. $145 \mathrm{Ma}$ (Masrour et al., 2004) and experienced diversification during the entire Cretaceous Period. Studies have shown a continuous developmental trend of the group during that interval (e.g., Villier and Eble, 2004). The first representatives (i.e., species of the genus Toxaster) were characteristic of offshore environments. Subsequently, various derived forms colonised warm and shallow waters of shoreface environments, thus augmenting the range of ecological niches occupied by spatangoids. During the Hauterivian-Aptian interval, the genus Heteraster was the commonest heart urchin along the margins of the Tethys Ocean, inhabiting upper offshore and lower shoreface settings that are represented mainly by orbitoline-rich marls and limestones (Masse and Humbert, 1976). Heteraster showed several phases of diversification that can be correlated to the colonisation of new palaeogeographical realms and the development of carbonate platforms. From the Hauterivian to Barremian, this genus diversified in the western Tethys. Its adaptive success resulted from morphological specialisation for more efficient gas exchange and better burrowing ability. This was coeval to the colonisation of new ecological niches in shallow-water platforms along the margins of the Urgonian facies. Heteraster became much more diverse and widespread during the late Barremian and early Aptian (c. 126-123 Ma) and remained the commonest and most diverse spatangoid throughout the Aptian (e.g., Yavari et al., 2016). However, new lineages differentiated in shallow waters by the end of the early Aptian, each with adaptive strategies to improve gas exchange the earliest members of the Macraster/Douvillaster 
clade (i.e., Douvillaster convexus) and of the family Micrasteridae (Epiaster polygonus). Heteraster, Douvillaster and Macraster remained the most widely distributed forms, but the Albian was marked by a clear differentiation of primitive representatives of the families Micrasteridae, Hemiasteridae and Schizasteridae - i.e., the earliest members of all modern groups of spatangoid echinoids.

Hemiasterids (Hemiaster) became specialised to muddy substrates in offshore settings and to cool, shallow-water carbonates, whereas schizasterids (Mecaster, Periaster and Polydesmaster) adapted to shallow and warmer waters. In the early Cenomanian, the Schizasteridae rapidly diversified and became the major spatangoid group. At the same time, diversity of Douvillaster dropped and the genera Heteraster and Macraster went extinct.

The demise of Macraster, Douvillaster and Heteraster might have been initiated by competition with the diversifying schizasterids that evolved more efficient structures for gas exchange and burrowing in shallow-water environments. Late Cenomanian and younger Cretaceous spatangoid communities were structured as follows: schizasterids and some hemiasterids in upper offshore and shoreface environments, and micrasterids in the mid-shelf zone (Saucède and Villier, 2005).

During this time, irregular echinoids switched to deposit feeding for the first time in the history of the clade. This ecological shift to graze feeding required the development of denser tube feet and, hence, pore pair crowding, necessitating the adoption of plate compounding. In time, the radiation of spatangoid echinoids directly followed the bloom of planktonic foraminifera and ancyloceratine ammonites (Figure 5).

\subsection{MEIOFAUNA}

The term 'meiofauna' refers to a range of metazoan components of the benthos, defined by body size $(42-1000 \mu \mathrm{m})$. These are the most diversified element amongst marine biota - in present-day settings as many as 23 of 33 animal phyla have meiobenthic representatives, either during their entire lifespan or just temporarily (Vincx, 1996). Today, meiofauna constitutes the most abundant

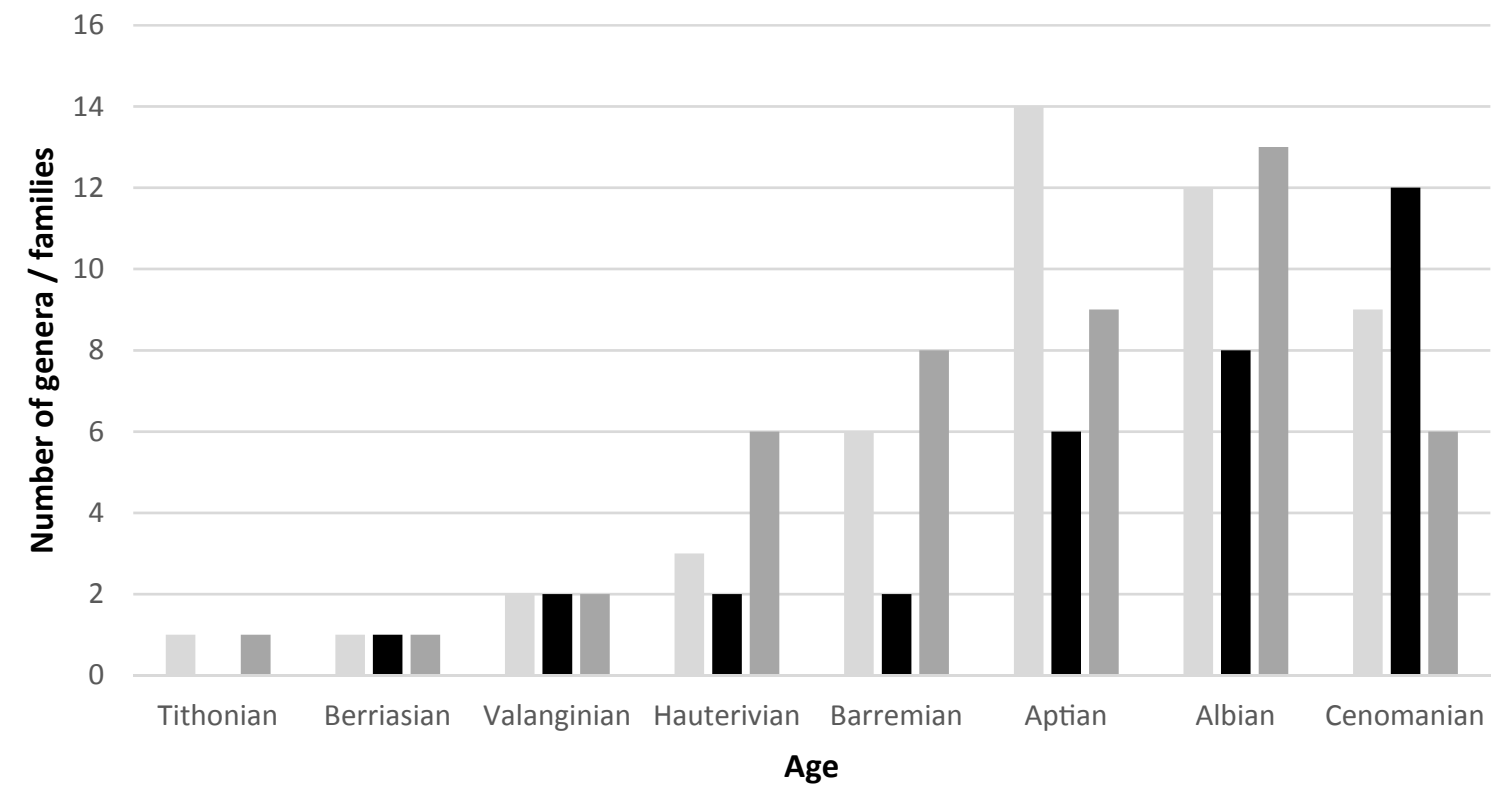

planktonic foraminifera

- spatangoid echinoids

ancyloceratine ammonites

Figure 5 Successive radiation and peaks in time of numbers of planktonic foraminiferal genera, of ancyloceratine ammonite families and of spatangoid echinoid genera (data from Villier et al., 2004; Rückheim, 2005; Mikhailova and Baraboshkin, 2009). 
benthic group in the marine realm, and is thought to be intimately linked to other faunal components of the benthic system. Amongst meiobenthic protozoans, foraminifera are the commonest and most diverse of shell-bearing micro-organisms in the oceans. The phylum Nematoda, meanwhile, is the most plentiful (often $>50$ per cent of total meiofauna, up to $>90$ per cent in deep-sea sediments) and diverse metazoan meiofauna taxon (Watzin, 1983; Wägele, 1989; Kalogeropoulou et al., 2010; Balsamo et al., 2012). The rise in abundance and diversity of meiofauna, triggered by the Late Jurassic-Cretaceous plankton bloom, in turn led to a radiation and increased areal distribution amongst a range of benthic groups that had previously been unable to inhabit offshore environments because of a general lack of food. In short, the phytoplankton radiation generated a bloom of zooplankton. The uninterrupted 'snowfall' of these two components offered new food sources and niches to occupy, first in shelf settings and later also in more basinal environments.

\subsection{RANINOIDIAN GRABS}

Prosopids and allied crabs, the most primitive among the brachyurans, flourished in sponge-microbial and coral-reef environments along the northern margin of the Tethys Ocean during the Late Jurassic, making good use of the numerous cryptic habitats within these environments (Jagt et al., 2015). The clade Gymnopleura (that is, Raninoidia), also known as frog crabs, form a group of brachyurans of which extant members are characterised by a fusiform carapace (palaeocorystid-lyreidid-raninid type), a narrow thoracic sternum, a pleon that is partially exposed dorsally and paddle-like limbs, all of which are well suited to their cryptic specialised burying (back-burrowing) lifestyle. Nevertheless, the most basal gymnopleurans were morphologically different, with ornamented carapaces that were wider than long (necrocarcinid-type) and had a broader thoracic sternum and a pleon that fit between the legs, assisted by pleonal locking mechanisms (Luque et al., 2012).
Luque et al. (2012) noted that the Gymnopleura was one of the major brachyuran groups to have adapted to inhabit soft and sandy sediments across a wide bathymetric range, from tropical to low-latitude regions across the globe. The first raninoidian known to date is from the uppermost Jurassic reefal limestones of Štramberk, Czech Republic (pers. obs.). From a basic hexagonal necrocarcinid morphotype (shallow-marine reef inhabitants) arose the fusiform palaeocorystid morphotype (burying within fine-grained, soft sediments).

Extant Raninoides lamarcki still shows a scavenger mode of food acquisition of invertebrates (meiofauna) (Soto and Escobar-Briones, 1995). Rosa and Bemvenuti (2005) showed that meiofauna community structure was negatively affected by the burrowing crab Chasmagnathus granulata (Dana, 1851).

Until recently, the oldest record of a gymnopleuran was that of Paranecrocarcinus hexagonalis Van Straelen, 1936 from the Hauterivian of Migraine, near Auxerre (Yonne, France). During the Aptian, necrocarcinids were already diverse and widely distributed worldwide (e.g., Van Bakel et al., 2012; Schweitzer et al., 2016), whereas the first palaeocorystoid appeared in Colombia (Luque et al., 2012; Luque, 2014). During the Albian both types occurred globally and in large numbers, mostly in shale-rich deposits. Although numerous studies on the earliest gymnopleurans have recognised the order of appearance of the various morphotypes, the successive diversity peaks (Figure 6), and an increase of gymnopleurity over time, a model to explain these changes has not yet been proposed.

The phylogenetic relationships of palaeocorystoids have recently been revised by Van Bakel et al. (2012), who concluded that the Palaeocorystidae Lőrenthey in Lőrenthey and Beurlen, 1929 was the most specialised family that was characterised by a back-burrowing mode of life. In view of the fact that the new niche was in relatively deeper-marine environments with predominantly shale-like deposits that lacked crevices and other places for crabs to hide in (such as those in reefal settings), a burying lifestyle was a prerequisite for 


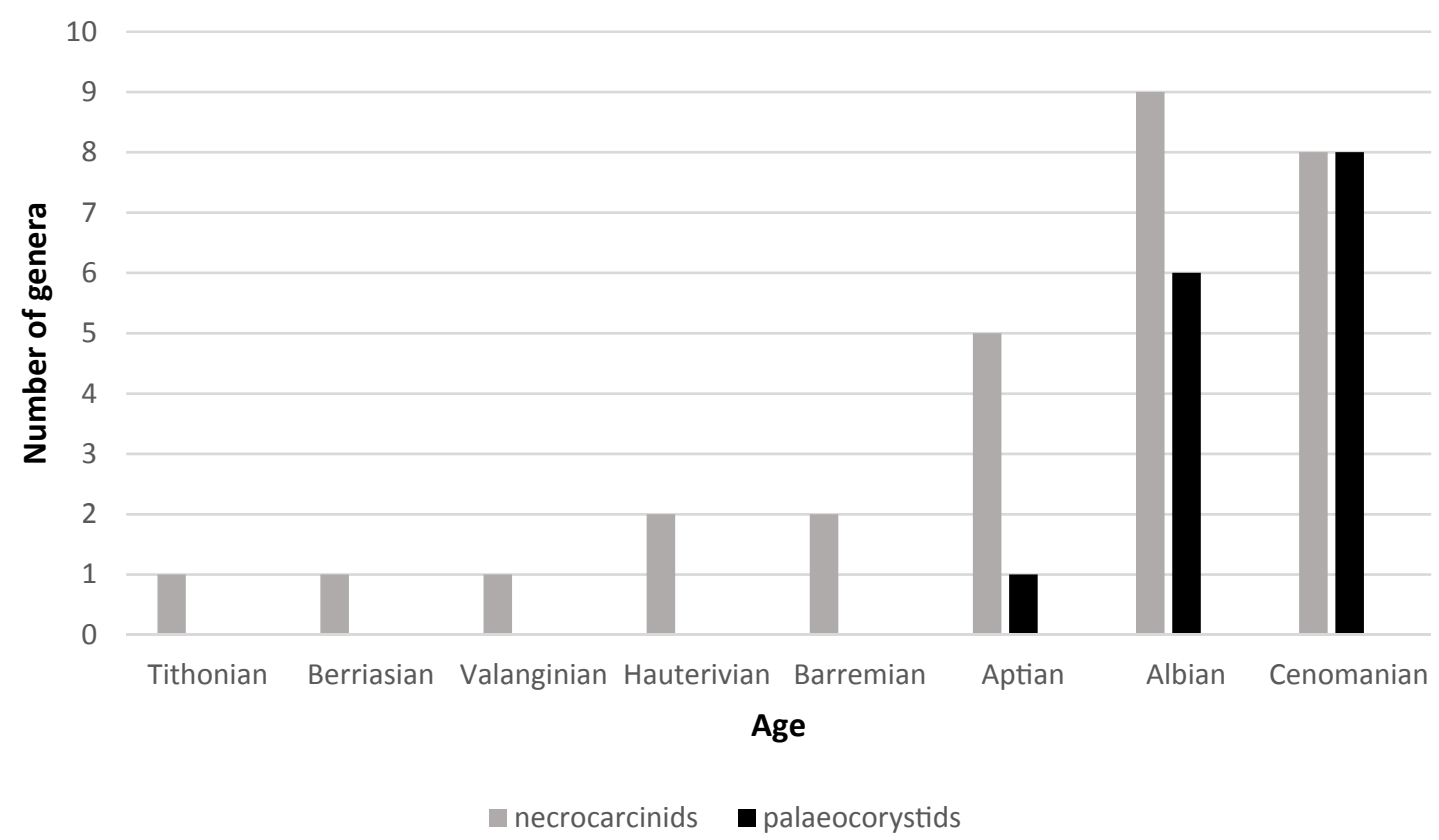

Figure 6 Successive radiation in time of necrocarcinid- and palaeocorystid-type crab genera (numbers) (data from Luque et al., 2012; Van Bakel et al., 2012; Karasawa et al., 2014, Schweitzer et al., 2016; pers. obs.).

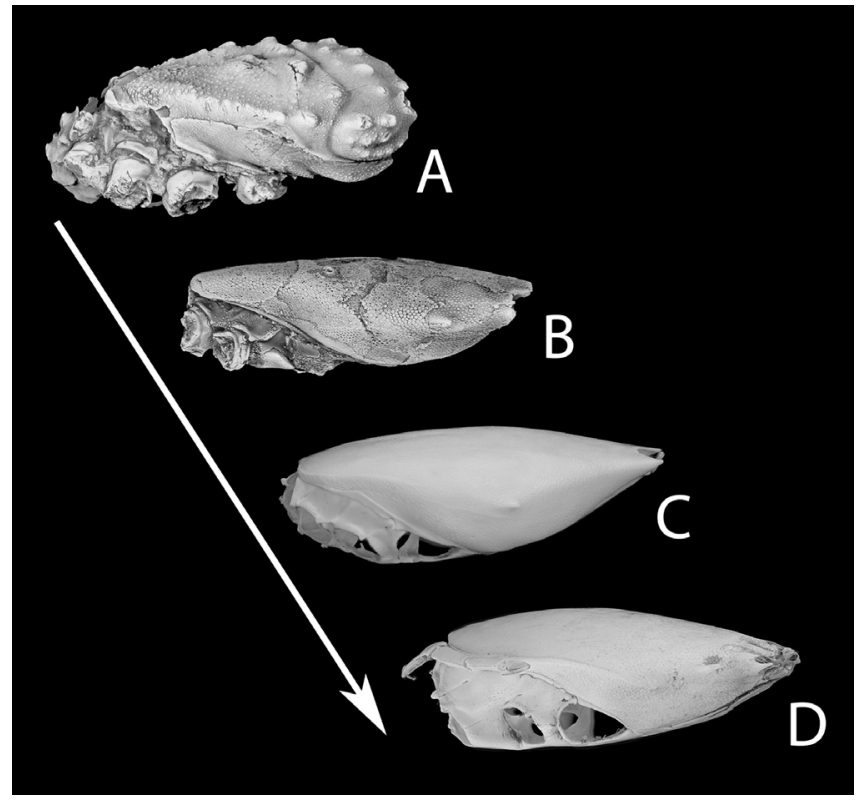

Figure 7 From palaeocorystoid (no external gymnopleurity; A, B), via lyreidid (increased gymnopleurity; C) to raninid morphotype (most conspicuous gymnopleurity; D), documenting nichereplacement events over time. survival. A major step in developing a shape that was advantageous to such a mode of life involved a series of coherent adaptations (a narrowing of the body, minimisation of the posterior thoracic sternal surface, development of arthrodial cavities in a more axial position and exposure of the pleurites) (Figure 7).

After having been successfully adapted to a burying lifestyle and filling this new marine niche worldwide, the predator-pressure by, for example, fishes and ammonites increased. Driven by this predator-pressure, the mode of hiding/burying had to be improved. Apparently, the increase of gymnopleurity (reduced branchiostegites and exposed pleurae of the cephalothorax) and loss of conspicuous abdominal holding (a double peg on thoracic sternite 5) was most successful in that respect. 


\subsection{ETYIOID CRABS}

Förster (1968, p. 190) postulated that etyioids were derived from a necrocarcinid ancestor. In subsequent studies it has been inferred that etyioid crab taxa were able to swim (e.g., Bishop, 1991; Fraaye, 1996a, b). Bishop (1991) even transferred the genus Xanthosia Bell, 1863 to the Portunidae on the basis of carapace features. In view of the morphological similarity of Xanthosia to extant swimming crabs (portunids), an ancestral relationship seems quite possible (compare Wright and Collins, 1972). The most striking morphological features are the following: a thin, dorsally flattened carapace that is wider than long, with multiple spines on subrounded anterolateral margins and with large, widely spaced orbits. There is a general trend in time amongst etyioids from more ornamented carapaces (e.g., Steorrosia (Rathbun, 1935); Albian-Cenomanian) to smoother carapaces (e.g, the late Maastrichtian Cretachlorodius Fraaye, 1996a and early Paleocene Faksecarcinus Schweitzer, Feldmann, Franţescu and Klompmaker, 2012; see Fraaye, 1996b, p. 275) (Figure 8).

It is most likely that the first stage in the swimming mode amongst etyioids was connected to escape reactions in avoidance of predators. In time, the natatory capabilities improved to periods of feeding (capture of prey) and finally to the maintenance of a continued nektonic lifestyle.

Radwański (1996) documented paired punctures that pierced the shells of latest Maastrichtian scaphitid ammonites and interpreted them as having been produced by predatory crabs. Similar traces of damage on scaphitids are not uncommon in the Upper Cretaceous of North America (Takeda et al., 2016). Externally inflicted injuries, indicated by repaired damage on mature shells, account for an average incidence of 10 per cent in Maastrichtian scaphitids from North America,

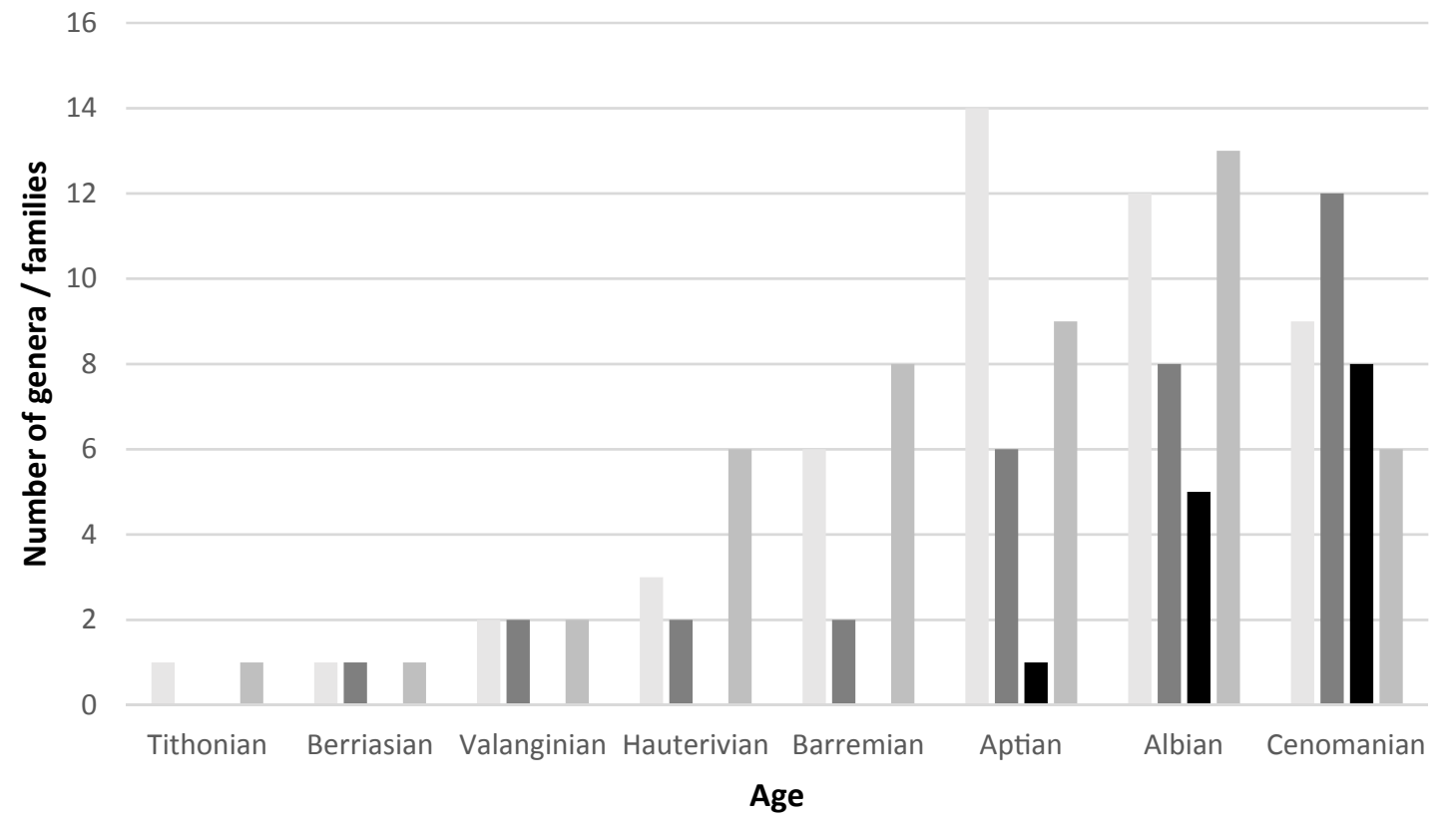

planktonic foraminifera spatangoid echinoids a palaeocorystid crabs ancyloceratine ammonites 
with the exception of the stratigraphically youngest latest Cretaceous levels where scaphitid injuries approach 40 per cent (Landman and Waage, 1986). Fraaye (1996b) subsequently postulated that the predation pressure on decapod crustaceans by, for instance, ammonites, might have led to an 'evolutionary' escape of natant etyioids at the end of the Cretaceous. In turn, these etyioids met with a new and abundant food source - scaphitid ammonites. Etyioids were ousted by better-adapted portunids during a faunal replacement event in the Paleogene (Fraaye, 1996b).

Quantitative patterns of decapod biodiversity through time were virtually unknown until the recent study by Klompmaker et al. (2013), who presented genus- and species-level diversity curves for different decapod groups in the Mesozoic. They concluded that the diversification of decapod crustaceans coincided with reef expansion and was followed by a severe diversity loss as reefs contracted, suggesting that reefs may have acted as ecosystem engineers over time. The evolution of raninoids and etyioids (Figure 9) are the first two documented examples of radiation in non-reefal settings.

\section{Conclusions}

Major Mesozoic evolutionary and radiation events among marine phyto- and zooplanktonic microbiota triggered, both directly and indirectly, the rise of new ecological niches and, concomitantly, evolutionary radiation of various marine benthic and nektonic groups. From the Late Jurassic onwards, the impact on marine invertebrate detritus and plankton feeders was direct. More complex scavenger/detritivore patterns (e.g., brachyuran decapod crustaceans) were intimately linked to the bloom of (part of) their food source (i.e., marine meiofauna). During the Cretaceous Period new innovations and adaptations brought about additional distinctive faunal turnovers in such groups as brachyuran decapod crustaceans, irregular echinoids and heteromorph ammonites. For the first time, a coherent bottom-up model for the Mesozoic marine revolution, from phytoplankton to diverse nektonic and benthic invertebrate groups, is presented here.

\section{Acknowledgements}

We thank Dr Adiël A. Klompmaker (University of California, Berkeley) for items of literature and Dr Michał Krobicki (Polish Geological Institute-National Research Institute, Kraków, Poland) and an anonymous reviewer for pertinent comments on an earlier version of the typescript.

\section{References}

Atkinson, A., Shreeve, R.S., Pakhomov, E.A., Priddle, J., Blight, S.P., Ward, P., 1996, Zooplankton response to a phytoplankton bloom near South Georgia, Antarctica: Marine Ecology Progress Series, 144, 195-210.

Balsamo, M., Semprucci, F., Frontalini, F., Coccioni, R., 2012, Meiofauna as a tool for marine ecosystem biomonitoring, in

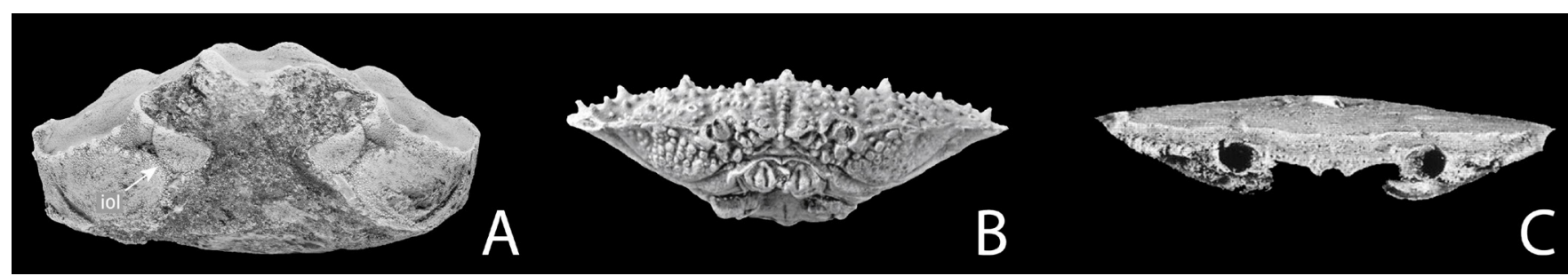

Figure 9 Successive radiation in time of numbers of necrocarcinid, palaeocorystid and etyid crab genera (data from Luque et al., 2012; Schweitzer et al., 2012; Van Bakel et al., 2012; Karasawa et al., 2014; Schweitzer et al., 2016). 
Cruzado, A. (ed.), Marine Ecosystems: InTech Publisher, 4, 77-104.

Bell, T., 1863, A monograph of the fossil malacostracous Crustacea of Great Britain. Part II. Crustacea of the Gault and Greensand. London, Monographs of the Palaeontographical Society London, 1863, viii $+1-40 \mathrm{p}$.

Bishop, G.A., 1991, Xanthosia occidentalis Bishop, 1985, and Xanthosia spinosa new species, two Late Cretaceous crabs from the Pierre Shale of the Western Interior: Journal of Crustacean Biology, 11, 305-314.

Bown, P.R., Lees, J.A., Young, J.R., 2004, Calcareous nannoplankton evolution and diversity through time, in Thierstein, H.R., Young, J.R. (eds.), Coccolithophores: from molecular process to global impact. Berlin, Springer. 481-508.

Brayard, A., Krumenacker, L., Botting, J.P., Jenks, J.F, Bylund, K.G., Fara, E., Vennin, E., Olivier, N., Goudemand, N., Saucède, T., Charbonnier, S., Romano, G., Doguzhaeva, L., Thuy, B., Hautmann, M., Stephen, D.A., Thomazo, C., Escarguel, G., 2017, Unexpected Early Triassic marine ecosystem and the rise of the modern evolutionary fauna: Science Advances 3, e1602159, 11 p.

Dana, J.D., 1851, Crustacea Grapsoidea, (Cyclometopa, Edwardsii): Conspectus Crustacearum quae in Orbis Terrarum circumnavigatione, Carolo Wilkes e classe Reipublicae Foederatae Duce, lexit et descriptsit J.D. Dana: Proceedings of the Academy of Natural Sciences of Philadelphia, 5, 247-254.

David, B., Mooi, R., Néraudeau, D., Saucède, T., Villier, L., 2009, Évolution et radiations adaptatives chez les échinides: Comptes Rendus Palevol, 8, 189-207.

Erbacher, J., Thurow, J., 1997, Influence of oceanic anoxic events on the evolution of mid-Cretaceous Radiolaria in the north Atlantic and western Tethys: Marine Micropalaeontology, 30, 139-158.
Förster, R., 1968, Paranecrocarcinus libanoticus n. sp. (Decapoda) und die Entwicklung der Calappidae in der Kreide: Mitteilungen aus der Bayerischen Staatssammlung für Paläontologie und historische Geologie, 8, 167-195.

Fraaye, R.H.B., 1996a, A new Tethyan migrant: Cretachlorodiusenciensisn. gen., n. sp. (Crustacea, Decapoda), from the Maastrichtian type area: Journal of Paleontology, 70, 293-296.

Fraaye, R.H.B., 1996b, Late Cretaceous swimming crabs: radiation, migration, competition, and extinction: Acta Geologica Polonica, 46, 269-278.

Jagt, J.W.M., Van Bakel, B.W.M., Guinot, D., Fraaije, R.H.B., Artal, P., 2015, Fossil Brachyura, in Castro, P., Davie, P.J.F., Guinot, D., Schram, F., Von Vaupel Klein, C. (eds.), Treatise on Zoology-Anatomy, Taxonomy, Biology - The Crustacea, complementary to the volumes translated from the French of the Traité de Zoologie, 9(G) (I), Decapoda: Brachyura (Part 1). Leiden Brill, 847-920.

Kalogeropoulou, V., Bett, B.J., Gooday, A.J., Lampadariou, N., Martinez-Arbizu, P., Vanreusel, A., 2010, Temporal changes (19891999) in deep-sea metazoan meiofaunal assemblages on the Porcupine Abyssal Plain, NE Atlantic: Deep-Sea Research Part II, 57, 1383-1395.

Karasawa, H, Schweitzer, C.E., Feldmann, R.M., Luque, J., 2014, Phylogeny and classification of Raninoida (Decapoda: Brachyura): Journal of Crustacean Biology, 34, 216-272.

Kier, P.M., 1982, Rapid evolution in echinoids: Palaeontology, 25, 1-9.

Klompmaker, A.A., Schweitzer, C.E., Feldmann, R.M., Kowalewski, M., 2013, The influence of reefs on the rise of Mesozoic marine crustaceans: Geology, 41, 1179-1182.

Knoll, A.H., Follows, M.J., 2016, A bottom-up perspective on ecosystem change in Mesozoic oceans, Proceedings of the Royal Society (London) B283: 20161755, http://dx.doi. org/10.1098/rspb.2016.1755, 10 p. 
Kroh, A., Smith, A.B., 2010, The phylogeny and classification of post-Palaeozoic echinoids: Journal of systematic Palaeontology, 8, $147-212$.

Kruta, I., Landman, N., Rouget, I., Cecca, F., Tafforeau, P., 2011, The role of ammonites in the Mesozoic marine food web revealed by jaw preservation: Science, 331, 70-72.

Kruta, I., Landman, N.H., Rouget, I., Cecca, F., Tafforeau, P., 2013, The radula of the Late Cretaceous scaphitid ammonite Rhaeboceras halli (Meek and Hayden, 1856). Palaeontology, 56, 9-14.

Landman, N.H., Waage, K.M., 1986, Shell abnormalities in scaphitid ammonites. Lethaia, 19, 211-224.

Landman, N.H., Goolaerts, S., Jagt, J.W.M., JagtYazykova, E.A., Machalski, M., Yacobucci, M.M., 2014, Ammonite extinction and nautilid survival at the end of the Cretaceous: Geology, 42, 707-710.

Landman, N.H., Goolaerts, S., Jagt, J.W.M., Jagt-Yazykova, E.A., Machalski, M., 2015, Ammonites on the brink of extinction: diversity, abundance, and ecology of the Order Ammonoidea at the Cretaceous/ Paleogene $(\mathrm{K} / \mathrm{Pg})$ boundary, in Klug, C., Korn, D., De Baets, K., Kruta, I., Mapes, R.H. (eds.), Ammonoid paleobiology: from macroevolution to paleogeography [Topics in Geology, 43/44]. Springer, Berlin/ Heidelberg. 497-553.

Lehmann, J., 2015, Ammonite biostratigraphy of the Cretaceous - an overview, in Klug, C., Korn, D., De Baets, K., Kruta, I., Mapes, R.H. (eds.), Ammonoid paleobiology: from macroevolution to paleogeography [Topics in Geology, 43/44]. Springer, Berlin/ Heidelberg. 403-429.

Lehmann, J., Ifrim, C., Bulot, L., Frau, C., 2015, Paleobiogeography of Early Cretaceous ammonoids, Ammonoid paleobiology: from macroevolution to paleogeography [Topics in Geology, 43/44]. Springer, Berlin/ Heidelberg, 229-257.
Linnaeus, C., 1758, Systema naturae per regna tria naturae, secundum classes, ordines, genera, species, cum characteribus, differentiis, synonymis, locis. Editio decima, reformata. Tomus I, Laurentius Salvius, Stockholm, 824 p.

Lőrenthey, E., Beurlen, K., 1929, Die fossilen Decapoden der Länder der Ungarischen Krone: Geologica Hungarica, Series Palaeontologica, 3, 1-420.

Luque, J., 2014, A new genus and species of raninoidian crab (Decapoda, Brachyura) from the Lower Cretaceous of Colombia, South America, in Fraaije, R.H.B., Hyžný, M., Jagt, J.W.M., Krobicki, M., Van Bakel, B.W.M. (eds.), Proceedings of the 5th Symposium on Mesozoic and Cenozoic decapod crustaceans, Krakow [sic], a tribute to Pál Mihály Müller, Poland 2013, Scripta Geologica, 147, 27-34.

Luque, J., Feldmann, R.M., Schweitzer, C.E., Jaramillo, G., Cameron, G.B., 2012, The oldest frog crabs (Decapoda: Brachyura: Raninoida) from the Aptian of northern South America: Journal of Crustacean Biology, 32, 405-420.

MacRae, R.A., Fensome, R.A., Williams, G.L., 1996, Fossil dinoflagellate diversity, originations, and extinctions and their significance: Canadian Journal of Botany, 74, 1687-1694.

Masrour, M., Aoutem, M., Atrops, F., 2004, Succession des peuplements d'échinides du Crétacé Inférieur dans le Haut Atlas atlantique (Maroc); révision systématique et intérêt stratigraphique: Geobios, 37, 595-617.

Masse, J.-P., Humbert, S., 1976, Les échinides du Crétacé inférieur provençal. Biostratigraphie et paléoécologie: Géologie Méditerranéenne, 3, 45-56.

Mikhailova, I.A., Baraboshkin, E.Yu., 2009, The evolution of the heteromorph and monomorph Early Cretaceous ammonites of the suborder Ancyloceratina Wiedmann: 
Paleontological Journal, 43, 527-536.

Monks, N., 1999, Cladistic analysis of Albian heteromorph ammonites: Palaeontology, 42, 907-925.

Olney, M., 2002, Radiolaria, University College London, Micropalaeontology Unit, www. ucl.ac.uk/GeolSci/micropal/radiolaria.html (accessed March 15, 2018).

Premoli-Silva, I., Sliter, W.V., 1999, Cretaceous paleoceanography: evidence from planktonic foraminiferal evolution, in Barrera, E., Johnson, C.C. (eds.), Evolution of the Cretaceous ocean-climate system: Geological Society of America, Special Paper, 332, 301-328.

Radwański, A., 1996, The predation upon, and the extinction of, the latest Maastrichtian populations of the ammonite species Hoploscaphites constrictus (J. Sowerby, 1817) from the Middle Vistula Valley, Central Poland: Acta Geologica Polonica, 46, 117-135.

Rathbun, M.J., 1935, Fossil Crustacea of the Atlantic and Gulf Coastal Plain: Geological Society of America, Special Paper, 2, 1-160.

Reháková, D., Michalík, J., 1997, Evolution and distribution of calpionellids-the most characteristic constituents of Lower Cretaceous Tethyan microplankton: Cretaceous Research, 18, 493-504.

Rosa, L.C., Bemvenuti, C.E., 2005, Effects of the burrowing crab Chasmagnathus granulata (Dana) on meiofauna of estuarine intertidal habitats of Patos Lagoon. Southern Brazilian Archives of Biology and Technology, 48, 267-274.

Rückheim, S., 2005. The onset of planktic foraminifera in the mid-Cretaceous of the Boreal Realm. Bochum, Germany, Fakultät für Geowissenschaften, Ruhr-Universität Bochum, unpublished $\mathrm{PhD}$ thesis, $82 \mathrm{p}$.

Saucède, T., Villier, L., 2005, The environmental context of spatangoid (Echinodermata: Echinoidea) evolution in the Early and Mid Cretaceous, in Arnaud-Vanneau, A., Arndt, N., Zghal, I. (eds.), Global events during the quiet Aptian-Turonian Superchron: Géologie Alpine, Série spéciale "Colloques et Excursions", 6, 59-61.

Schweitzer, C.E., Feldmann, R.M., Franţescu, O.D., Klompmaker, A.A., 2012, Revision of Etyidae Guinot and Tavares, 2001 (Crustacea: Brachyura). Journal of Paleontology, 86, 129-155.

Schweitzer, C.E., Karasawa, H., Luque, J., Feldmann, R.M., 2016, Phylogeny and classification of Necrocarcinoidea Förster, 1968 (Brachyura: Raninoida) with the description of two new genera: Journal of Crustacean Biology, 36, 338-372.

Smith, A.B., 1984, Echinoid palaeobiology,. George Allen \& Unwin, London, 190 p.

Soto, L.A., Escobar-Briones, E., 1995, Coupling mechanisms related to benthic production in the SW Gulf of Mexico, in Eleftheriou, A., Ansell, A.D., Smith, C.J. (eds.), Proceedings of the 28th European Marine Biology Symposium 1993, Iraklion, Crete: Olsen \& Olsen, Fredensborg, 233-244.

Takeda, Y., Tanabe, K., Sasaki, T., Landman, N.H., 2016, Durophagous predation on scaphitid ammonoids in the Late Cretaceous Western Interior Seaway of North America: Lethaia, 49, 28-42.

Van Bakel, B.W.M., Guinot, D., Artal, P., Fraaije, R.H.B., Jagt, J.W.M., 2012, A revision of the Palaeocorystoidea and the phylogeny of raninoidian crabs (Crustacea, Decapoda, Brachyura, Podotremata): Zootaxa, 3215, $1-216$.

Van Straelen, V., 1936, Crustacés décapodes nouveaux ou peu connus de l'époque Crétacique: Bulletin du Musée royal d'Histoire naturelle de Belgique, 12, 1-50.

Vermeij, G.J., 1987, Evolution and escalation: an ecological history of life, Princeton, New Jersey, Princeton University Press, 527 p.

Villier, L., Eble, G., 2004, Assessing the robustness of disparity estimates: the impact of morphometric scheme, temporal scale, and taxonomic level in spatangoid echinoids: 
Paleobiology, 30, 652-665.

Villier, L., Néraudeau, D., Clavel, B., Neumann, C., David, B., 2004, Phylogeny of Early Cretaceous spatangoids (Echinodermata: Echinoidea) and taxonomic implications: Palaeontology, 47, 265-292.

Vincx, M., 1996, Meiofauna in marine and freshwater sediments, in Hall, G.S. (ed.), Methods for the examination of organismal diversity in soils and sediments, $\mathrm{CAB}$ International, Wallingford, 187-195.

Wägele, J.W., 1989, On the influence of fishes on the evolution of benthic crustaceans: Zeitschrift für zoologische Systematik und Evolutionsforschung, 27, 297-309.
Watzin, M.C., 1983, The effects of meiofauna on settling macrofaunal meiofauna may structure macrofaunal communities: Oecologia, 59, 163-166.

Wright, C.W., Collins, J.S.H., 1972, British Cretaceous crabs: Monographs of the Palaeontographical Society London, 126 (533), $114 \mathrm{p}$.

Yavari, M., Yazdi, M., Gahalavand, H., Kamyabi Shadan, H., Adabi, M.H., Villier, L., 2016, Early Cretaceous toxasterid echinoid Heteraster from the High Zagros Basin, south of Iran: Carnets de Géologie/Notebooks of Geology, 16 (26), 615-632. 